\title{
A Study on the Relationship between Productive Services Trade and Goods Trade in Britain and Suggestions to China
}

\author{
Pang Bo ${ }^{1,2}$, Zhang Shuxiao", Xiong Pan ${ }^{1}$ \\ ${ }^{1}$ School of Economics, Northeast Normal University, Changchun 130117, China \\ ${ }^{2}$ College of Economics and Management, Beihua University, Jilin 132013, China
}

Keywords: Productive services trade; goods trade; relationship; impulse response analysis; variance decomposition

\begin{abstract}
With the Johansen co-integration test, Granger causality test, impulse response analysis and variance decomposition, this paper studies the dynamic relationship between productive services trade and goods trade in Britain. The results show that, the fluctuation of British goods trade volume is affected by its own impact factors and productive services trade, however, the fluctuation of British trade volume in productive services is mainly attributed to its own impact. Based on these, the important measures to promote the coordinated development of productive services trade and goods trade in UK are summarized, and corresponding proposals are put forward, combined with the actual situation in China.
\end{abstract}

\section{Introduction}

Since the global financial crisis in 2008, due to sluggish world economic recovery and the entry of China's economic development to the New Normal, the development of China's foreign trade enters the stage of stagnation. Faced with complicated domestic and international economic conditions, in the report of the $19^{\text {th }}$ National Congress of CPC, Xi Jinping clearly put forward the guidance policy of "expanding foreign trade, training new industry form and new mode of trade, and strengthening the opening of service industry to the outside world", confirming the status and role of service trade in national economy, and paying more attention to breaking through the bottleneck of foreign trade with the development of services trade, so as to realize the new development of foreign trade.

Whereas, services trade and goods trade are two important parts of foreign trade, depending on and complementing each other. Especially, the productive services trade in services trade, can provide the services required for the manufacturing industry, improve the productivity of manufacturing industry, and increase the technical content of products and the competitiveness in international market, so as to promote the development of goods trade. However, goods trade is the material basis of the existence and development of productive services trade. The realization of goods trade always be conducted with productive services trade, such as financial services, insurance services, transportation services, etc.

Therefore, how to promote the coordinated development of China's goods trade and productive services trade and dynamically integrate the two is an important project faced by China to open the new situation of foreign trade and realize its new development. In recent years, China's productive services trade is increasing continuously, however, because it requires higher technical contents and additional value, China is in deficit, which is expanding incessantly. At the same time, in UK, the representative of western developed countries, its productive services trade has been the important pillar of increasing national economy, and other commercial services, financial services and transportation services even are in the leading position in the world. Based on Britain productive services trade, the research on the dynamic relationship between it and goods trade can provide valuable reference and significance for the development of China's relative trade.

From current domestic literature, there are three kinds of relationship between services trade and goods trade. First of all, the two promotes their development each other. Marrewijk, Stibora, Vaal 
(1996) [1] adopt general equilibrium model to analyze the relevance of services trade and goods trade, and think that there is the country with productive services market who export productive services and import trade goods. Xia Qing (2004) [2] and Qu Fengjie (2006) [3] think that services trade and goods trade promote their development each other, the former creating conditions for the structure optimization and industry transformation and upgrading of the latter, and the latter creating derived demand for the former. Zhuang Lijuan, and Chen Cuilan (2009) [4] believe that goods trade and services trade promotes each other, and the promoting effect of services trade on goods trade mainly comes from productive services trade department. Secondly, the relationship between services trade and goods trade is complementary in total volume and substituting in balance. Melvin (1989) [5] finds out that in the country with surplus of services trade, there will be a deficit in goods trade. Jones and Ruane (1990) [6] adopt the competition model to study the relationship, and find out that the increase of services trade export will reduce the goods trade export. Xie Kang and Li Zan (2000) [7] believe that there is the significantly negative correlation between the net values of goods trade and services trade in developed countries, which is not significant in developing countries. Zhou Yan and Zheng ganshu (2007) [8] analyze the data of related main countries, and find out that services trade and goods trade are complementary in total volume, and obviously substituting in their balance. Li Bingqiang and Lu Yuduo (2009) [9] analyze the data of trade total volume and balance of 131 countries, and find out that there is complementary relationship between services trade and goods trade in short term, however, in long term, the total volume is substituting and the balance is complementary. Yao Xing, Liu Xiaochai and Huang Feng (2011) [10] analyze the trade total volume and balance of structure of 143 countries, and conclude that services trade can promote goods trade, and the promoting effect mainly comes from producer services. In production, the balance of services trade and goods trade is complementary in short term, but substituting in long term. Thirdly, there is single-way promoting effect between services trade and goods trade. Cheng Dazhong and Chen Xian (2000) [11] think that the development of productive services trade originates from service demand caused by the development of goods trade. Wang Ying (2010) [12] believes that China's goods trade promotes services trade, mainly showing that goods trade promoting the import of services, however, the effect of goods trade on service export is not significant. Zhang Baoyou, Xiao Wen and Meng Lijun (2012) [13] conclude that in general, the increase of China's services trade export is conductive to improving the competitiveness of manufacturing export. Zhang Hui (2014) [14] makes a conclusion that the import volume and export volume of goods trade have a significant influence on China's services trade. Zhang Yan, Yu Lixin and Meng Fei (2015) [15] find out that general trade promotes the export of services in Zhejiang Province; whereas, processing trade significantly promotes the import of services. Bi Yujiang (2016) [16] concludes that the development of goods trade drives the export and import of services trade.

Researches show that there is still some space for research in this field. On one hand, previous researches are mainly the relationship analysis of services trade and goods trade, however, there is few researches on long-term equilibrium relationship and dynamic relationship between productive services trade and goods trade; on the other hand, there are fewer studies on the relationship between productive services trade and goods trade in developed countries. Britain, as a typical country with advanced development of productive services trade, relative studies on Britain will provide reference for China. Therefore, this paper conduct a detailed analysis on the dynamic relationship between productive services trade and goods trade in Britain with relevant econometric model.

\section{Data Selection and Empirical Analysis}

\subsection{Data selection and pre-processing}

In order to comprehensively study the relevance of Britain productive services trade and goods trade, and disclose the internal action mechanism of both, this paper uses $\mathrm{X}$ to stand for the total volume of Britain productive services trade, $\mathrm{Y}$ for the total volume of Britain goods trade, and the 
range of samples selected is between 1997 to 2016. Data comes from The Office of National Statistics. In this paper, Eviews8.0 data analysis software is used for all econometric analysis. To avoid the difference in orders of magnitude and obtain elastic estimated results, this paper conducts logarithmic converter on X and Y, and mark as LNX and LNY respectively. The descriptive statistics characteristics is shown in Table 1.

Table 1 The descriptive statistics characteristics

\begin{tabular}{ccccccc}
\hline Variable & $\begin{array}{c}\text { Mean } \\
\text { value }\end{array}$ & $\begin{array}{c}\text { Standard } \\
\text { deviation }\end{array}$ & Skewness & Kurtosis & J-B & P-value \\
\hline LNX & 7.4347 & 0.4195 & -0.3914 & 1.8035 & 1.7038 & 0.4266 \\
LNY & 8.5690 & 0.2641 & -0.1224 & 1.5701 & 1.7537 & 0.4161 \\
\hline
\end{tabular}

From Table 1, the mean value of LNX and LNY is 7.4347 and 8.5690 , respectively, the coefficients of skewness are all negative values, the coefficients of kurtosis are less than 3 , showing a platykurtosis left-skewed distribution, JB statistics are small, and P-values are all greater than the significance level of $10 \%$. Do not reject null hypothesis. The sequence distribution obeys normal distribution.

\subsection{Unit root test}

Since the random law of non-stationary time series is different at each time point, only when the time series used is a stationary time series, the phenomenon of "pseudo-regression" can be effectively avoided. Therefore, it is necessary to conduct stationary test on the time series of the observation value. In this paper, ADF test is used for LNX, LNY and the first order difference. The test results are shown in Table 2.

Table 2 ADF Test of variables

\begin{tabular}{ccc}
\hline variable & T-statistics & P-value \\
\hline LNX & -0.5461 & 0.9706 \\
$\Delta \ln X$ & -4.2719 & 0.0174 \\
LNY & -2.8910 & 0.1865 \\
$\Delta \ln Y$ & -5.6774 & 0.0013 \\
\hline
\end{tabular}

From test results in Table 2, LNX and LNY all do not reject null hypothesis in the significance level of $1 \%, 5 \%$ and $10 \%$, however, all reject null hypothesis after the first order difference, which shows that LNX and LNY are first order integrated. It can be said that there is conditions for co-integration relationship between LNX and LNY, satisfying relative premises of co-integration test.

\subsection{Johansen co-integration test}

This paper conducts co-integration test on relative variables with variable system maximum likelihood method proposed by Johansen et al in 1995. Specific results are shown in Table 3.

Table 3 Results of Johansen co-integration test

\begin{tabular}{ccccc}
\hline \multicolumn{5}{c}{ Unrestricted Cointegration Rank Test (Trace) } \\
\hline $\begin{array}{c}\text { Hypothesized } \\
\text { No.of CE(s) }\end{array}$ & Eigenvalue & Trace & 0.05 & Prob. \\
\hline None* $^{*}$ & 0.4445 & 15.5290 & 15.4947 & 0.0494 \\
At most ${ }^{*}$ & 0.2403 & 4.9458 & 3.8415 & 0.0261 \\
\hline LNY & LNX & C & & \\
1.000000 & -0.441809 & -5.282726 & & \\
& $(0.06660)$ & & & \\
\hline
\end{tabular}

In Johansen co-integration test, the test results of Trace Statistics are often more effective than the test results of the largest Eigenvalue. Therefore, according to Table 3, the test results of Trace Statistics reject the null hypothesis that there is no co-integration relationship, and reject the null hypothesis that there is at most one co-integration relationship. And because there is at most one co-integration relationship between the two variables, therefore, at the significance level of 5\%, it 
can be considered that there is a long-term stable equilibrium relationship between LNX and LNY, that is, the co-integration relationship. The final column shows the specific results of this co-integration relationship: $\operatorname{In} Y_{t}=5.282726+0.441809 \ln X_{t}+e_{t}$. It can be seen that when the long-term equilibrium is reached, in terms of quantitative relationship, if the total volume of British productive services trade changes by $1 \%$, the total volume of British goods trade will change by $0.441809 \%$.

\subsection{Granger causality test}

There is at least one Granger causality between the variables with co-integration relationship. Therefore, it is necessary to carry out the Granger causality test on LNX and LNY. Before performing the Granger causality test, this paper first constructs the VAR model and determines the optimal lag order, which is the basis for the subsequent Granger causality test, the impulse response function and variance decomposition. Table 4 shows the judgment results of the VAR model lag order using LNX and LNY.

Table 4 The judgment results of the VAR model lag order

\begin{tabular}{ccccccc}
\hline Lag & LogL & LR & FPE & AIC & SC & HQ \\
\hline 0 & 21.0316 & NA & 0.000318 & -2.378946 & -2.282372 & -2.374001 \\
1 & 60.6197 & $64.33075^{*}$ & $3.75 e-06^{*}$ & $-6.827465^{*}$ & $-6.537744^{*}$ & $-6.812629^{*}$ \\
2 & 61.6441 & 1.408559 & $5.63 E-06$ & -6.455516 & -5.972648 & -6.430789 \\
3 & 64.7880 & 3.538829 & $6.80 \mathrm{E}-06$ & -6.348719 & -5.672704 & -6.314101 \\
4 & 66.0375 & 1.091785 & $1.14 \mathrm{E}-05$ & -6.004688 & -5.135526 & -5.96018 \\
\hline
\end{tabular}

It can be seen from Table 4 that the LR, FPE, AIC, SIC and HQ criteria all point to the same first order lag period. According to the "Majority Principle", the optimal lag period is 1, and the corresponding Granger causality test results are shown in Table 5.

Table 5 Granger causality test results

\begin{tabular}{cccc}
\hline Null Hypothesis & Obs & F-Statistics & Prob. \\
\hline LNY is not Granger cause of LNX & 19 & 1.1716 & 0.2951 \\
LNX is not Granger cause of LNY & 19 & 10.2424 & 0.0056 \\
\hline
\end{tabular}

It can be seen from Table 5 that under the null hypothesis that LNY is not the Granger cause of LNX, F-statistics is not significant and cannot reject the null hypothesis, so goods trade is not the Granger cause of productive services trade. Under the null hypothesis that LNX is not the Granger cause of LNY, F-statistics is significant and rejects the null hypothesis, so productive services trade is not the Granger cause of goods trade.

\subsection{The impulse response analysis}

In general, the impulse response function is used to measure the variation trajectory of a standard deviation shock from a random disturbance term affecting the current and future values of the endogenous variable, so that the dynamic correlation between the variables can be relatively intuitively reflected. Through the impulse response analysis, the dynamic response path between the UK's producer services trade and goods trade can be visually seen. 

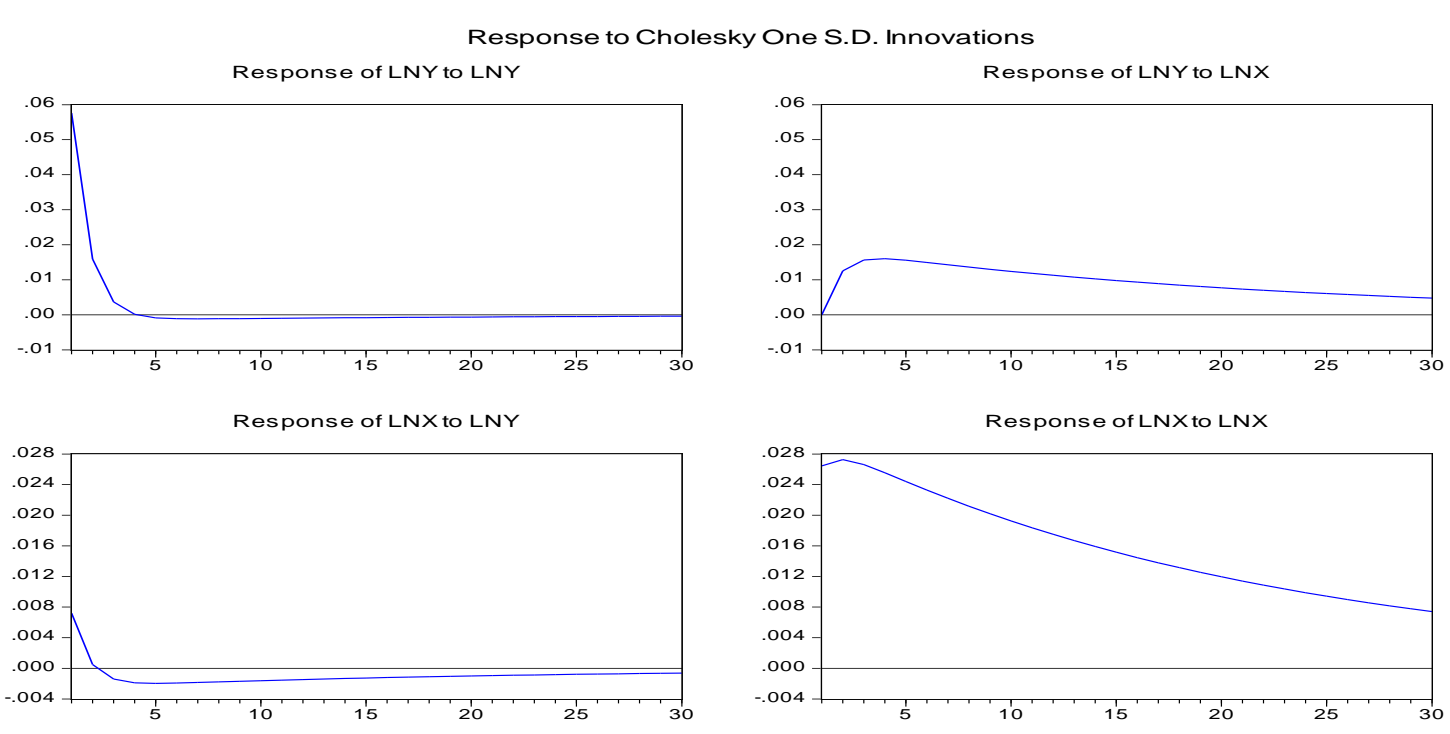

Figure 1 The impulse response function of VAR model

From Figure 1, when the LNY sequence is subjected to a unit positive random impact, it immediately "jumps" itself, then falls rapidly and returns to its original level in the fourth period. Correspondingly, the LNX sequence slightly "jumps" in the current period, then rapidly falls below the original level, and begins to slowly decline to the original level after reaching the lowest point in the fifth period. When the LNX sequence is subjected to a unit random perturbation factor, it immediately "jumps" itself, then rises slightly and reaches its highest point in the second period, and then slowly falls to the original level. Correspondingly, the LNY sequence did not change in the current period. From the next period, the LNY sequence rose rapidly and reached the highest point in the third period, and the highest point remained until the fifth stage, and then began to gradually decline back to the original level. Therefore, it can be seen that the hysteresis effect of the shock of the UK's productive services trade on the impact of its own random shock is far stronger than goods trade.

Two conclusions can be roughly summed up. Firstly, British goods trade is obviously more resistant to impact than productive services trade, which is mainly reflected by the rapid falling and returning of goods trade to its original level in the fourth period after a shock of positive standard deviation. Whereas, productive service trade strengthened the impact of the shock to some extent in the initial stage of the shock, and then slowly declined to gradually reach the original level. Secondly, in the random impact of the other party, the positive shock of productive services trade has a positive effect and a long-lasting effect on goods trade, while the positive shock of goods trade has a reverse inhibition and a long-lasting effect on productive services trade.

\subsection{Variance decomposition}

Because the variance of each variable in the VAR model system can be decomposed into the individual disturbance terms by variance decomposition, the degree of influence of each disturbance factor on each variable in the model can be obtained by variance decomposition.

Table 6 Variance analysis results of VAR model

\begin{tabular}{cccc}
\hline \multicolumn{4}{c}{ Variance Decomposition of LNY: } \\
\hline Period & S.E. & LNX & LNY \\
1 & 0.0274 & 0 & 100 \\
2 & 0.0387 & 4.2138 & 95.7862 \\
3 & 0.0470 & 10.0797 & 89.9203 \\
4 & 0.0535 & 15.5080 & 84.4920 \\
5 & 0.0588 & 20.0767 & 79.9233 \\
6 & 0.0633 & 23.8624 & 76.1376 \\
7 & 0.0671 & 27.0141 & 72.9859 \\
\hline
\end{tabular}




\begin{tabular}{cccc}
\hline 8 & 0.0704 & 29.6620 & 70.3380 \\
9 & 0.0733 & 31.9067 & 68.0933 \\
10 & 0.0758 & 33.8255 & 66.1745 \\
\hline \multicolumn{4}{c}{ Variance Decomposition of LNX: } \\
\hline Period & S.E. & LNX & LNY \\
1 & 0.0576 & 93.0759 & 6.9241 \\
2 & 0.0610 & 96.5039 & 3.4961 \\
3 & 0.0632 & 97.5388 & 2.4612 \\
4 & 0.0652 & 97.9770 & 2.0231 \\
5 & 0.0670 & 98.2147 & 1.7853 \\
6 & 0.0687 & 98.3648 & 1.6352 \\
7 & 0.0702 & 98.4687 & 1.5313 \\
8 & 0.0715 & 98.5447 & 1.4553 \\
9 & 0.0727 & 98.6027 & 1.3973 \\
10 & 0.0737 & 98.6482 & 1.3518 \\
\hline
\end{tabular}

Cholesky Ordering: LNY LNX

From Table 6, on the one hand, the fluctuation of the total volume of British goods trade is affected by the combination of its own impact factors and the disturbance factors of goods trade, but with the extension of the lag order, the impact of its own impact decreases slowly, but the impact of disturbance factors of goods trade slowly increases. On the other hand, the fluctuation of the total volume of British productive services trade is mainly due to its own impact, but is less affected by the disturbance factor of the total volume of productive services trade, and its own impact slowly increases with the extension of the lag order, while the disturbance factor of total volume of productive services trade is slowly decreasing.

\section{Conclusions and Countermeasures}

\subsection{Conclusions}

According to test results, it can be concluded that there is a long-term equilibrium relationship between British productive services trade and goods trade. However, according to Granger causality test, it can be found that, on the one hand, British goods trade is not the Granger cause of productive services trade. Although Granger cause is not economic cause, it explains to a certain extent that the growth of British goods trade cannot significantly drive the development of productive services trade. In theory, goods trade can provide a material basis for productive services trade and promote its development. However, after the 1970s, the development of goods trade was relatively slow due to the "de-industrialization" strategy in Britain and the massive export capital. In the same period, with the development of economic globalization, Britain, with its capital and technological advantages, vigorously developed knowledge-industry-intensive industries, which benefited the productive services trade. It can be seen that the growth of British goods trade is not obvious for the development of productive services trade.

On the other hand, British productive services trade is the Granger cause of the growth of goods trade, which indicates that the growth of British productive services trade will significantly increase goods trade. After entering the 21st century, Britain increased its investment in basic scientific research and technological innovation. As a result, productive services trade represented by other commercial services, financial services and transportation services has achieved rapid development and its contribution to the national economy has gradually increased. There is a certain gap between productive services trade and goods trade in total volume, however, the driving force of the development of goods trade has become increasingly prominent. Taking British transportation services trade as an example, Britain has further increased the introduction of foreign superior transportation equipment through the development of transportation services trade. In this way, transportation services trade developed more rapidly, and effectively promoted the growth of domestic goods trade. 
According to previous analysis results, it can be concluded that there is a dynamic relationship between productive services trade and goods trade in Britain. Whether British productive services trade or goods trade, its growth momentum is mainly derived from itself. The level of British productive services trade has long been at the forefront of the world, and highly advanced productive services trade will promote its own development. Taking financial services trade as an example, London, always one of the most important international financial centers in the world, with a comprehensive development mechanism, has attracted a large number of financial institutions, professionals and customers from around the world. The "aggregation effect" has further promoted the development of financial services trade. In addition, Britain emphasizes the basic driving force of basic research and technological innovation for the development of productive services trade, and promotes the international competitiveness of British productive services trade. The development of British productive services trade has provided more convenience and guarantee for the expansion of the scale of goods trade. In the long run, British productive services trade is bound to further promote the development of goods trade.

\subsection{Countermeasures and suggestions}

In view of the correlation between productive services trade and goods trade, after the Second World War, British government adopted various measures to promote the development of the two. The two most important ones are worth learning for China.

Since the 1960s, British government has vigorously developed service outsourcing through state-owned enterprise transformation and corporate restructuring, prompting manufacturing enterprises to transfer service links in the production process to more professional service providers, especially after the first oil crisis in 1973, British government has accelerated this process. By outsourcing transportation, finance, insurance and other services, the production cost is reduced and the production efficiency is improved, so that enterprises can focus on improving the core competitiveness of the product itself, which not only accelerates the development of the manufacturing industry, but also drives the growth of goods trade. And it has also greatly increased the demand for productive services by manufacturing enterprises, and promoted the rapid development of British productive services trade.

Compared with Britain, China's service outsourcing development is relatively late. There is only more than ten years since it was paid attention to in 2006. Although it has developed rapidly, the number of enterprises has increased substantially, and the transaction scale has increased day by day, the relevance between China's manufacturing enterprises and productive service enterprises is not high. Many manufacturing companies have not completely outsourced productive services, still leaving some productive service departments inside enterprises, corresponding production services are also completed by the internal organizations of manufacturing enterprises, resulting in insufficient demand for external productive service enterprises. In the face of this situation, China should learn from the experience of the United Kingdom, continue to increase the intensity of state-owned enterprise transformation and corporate restructuring, change the business philosophy, and enable more productive services to be separated from manufacturing enterprises, thus reducing the production of manufacturing enterprises, and increasing production efficiency, which is conductive to enhancing the competitiveness of manufacturing industry, and increasing the export of goods. At the same time, the increased demand for external productive services by manufacturing enterprises will drive the growth of productive services trade.

Since the "financial explosion" in the 1980s, British government has realized the full opening of the domestic financial market, successfully attracting a large number of foreign financial institutions, in the fierce market competition, which not only improves the level of domestic financial services and international competitiveness, also broadens the financing channels for productive service enterprises and manufacturing enterprises, making financing more diversified and convenient, laying a solid capital foundation for the rapid development of productive services and manufacturing, and promoting coordinated development of productive services trade and goods trade. 
After the access to the WTO, China gradually conduct the opening-up in accordance with the WTO access principle, but the overall openness of productive services is not high. There are many restrictions for the access of foreign capital market in financial, insurance and other departments. This has led to a large gap between China's productive service sector and the international market in terms of market infrastructure, business philosophy and technical experience, which has seriously hindered the further development of China's productive services trade. At present, Chinese government has realized the importance of expanding opening-up to improve the international competitiveness of productive services trade. President Xi Jinping emphasized in the report of the 19th National Congress of CPC that in order to better develop services trade, it is necessary to actively open up the domestic market and reduce market access restrictions and government intervention. China should expand the scope of opening-up of productive services, broaden the scope of openness, and deepen the level of openness. In this process, financial services can be used as a breakthrough in development, to effectively promote the opening-up of financial services, attract financial institutions from other countries in the world to enter China, and increase the import of high-quality high-end services, which will not only force domestic financial services to transform business ideas, improve the quality of service, enhance international competitiveness, further promote the development of productive services trade, and also provide more diversified and convenient financing services for manufacturing enterprises, to help them solve various financial problems, and help China's goods trade break through the current development bottleneck.

\section{References}

[1] Marrewijk, C.Van, J.Stibora, A.de Vaal. Services Tradability Trade Liberalization and Foreign Direct Investment [J]. Economica, 1996 (63):11-31.

[2] Xia Qing. On Coordinated Development of Commodity Trade and Service Trade [J]. Journal of International Trade, 2004(8):17-21.

[3] Qu Fengjie. Service Trade Development \& Strategic Measures for Chinese Foreign Trade Development [J]. Intertrade, 2006(1):28-32.

[4] Zhuang Lijuan, Chen Cuilan. The Dynamic Correlation Research on China's Services Trade and Goods Trade-Empirical Analysis Base on Impulse Response Function [J]. Journal of International Trade, 2009(2):54-60.

[5] Melvin James R. Trade in Producer Services: A Heckscher-Ohlin Approach [J]. Journal of Political Economy, 1989,97(5):1180-1196.

[6] Jones R W, Ruane F. Appraising the Options for International Trade in Services [J]. Oxford Economic Papers, 1990,42(4):672-687.

[7] Xie Kang, Li Zan. Empirical Analysis on Complementarity of Goods Trade and Service Trade The Essence of China and American Trade Imbalance [J]. Journal of International Trade, 2000(9):47-52.

[8] Zhou Yan, Zheng Ganshu. The Trade of Goods and Service: The Complementary Total Payments and The Substitute Relationship of the Balance of Payment [J]. Asia-Pacific Economic Review, 2007(2):93-96.

[9] Li Bingqiang, Lu Yuduo. Analysis on Substitution and Differentiation between Service Trade and Merchandise Trade [J]. Finance and Trade Research, 2009(1):55-60.

[10] Yao Xing, Liu Xiaochai, Huang Feng. Research on Dynamic Relationship between Goods Trade and Services Trade -Based on Empirical Analysis of Data from 1982 to 2008 from 143 Countries [J]. Macroeconomics, 2011(9):53-60.

[11] Cheng Dazhong, Chen Xian. Research on Services Trade Theory: Realistic Foundation, Overall Condition and Preliminary Thoughts [J]. Shanghai Journal of Economics, 2000(12):59-64. 
[12] Wang Ying. The Stimulative Effect of Chinese Commodity Trade on Its Service Trade: An Empirical Analysis based on Service Trade Gravity Model [J]. World Economy Study, 2010(7):45-48.

[13] Zhang Baoyou, Xiao Wen, Meng Lijun. The Relationship between Imports of Services and Manufacturing Export Competitiveness in China [J]. Economic Geography, 2012(1):102-108.

[14] Zhang Hui. An Empirical Study on the Influencing Factor and Trend of China's Services Trade

Competitiveness Based on the Data of 1982 2011 [J]. International Economic and Trade Research, 2014(6):56-67.

[15] Zhang Yan, Yu Lixin, Meng Fei. Synergetic Development Path between Trade in Services and Trade in Goods of China__Empirical Analysis Based on Zhejiang Experience [J]. Finance \& Trade Economics, 2015(1):105-116.

[16] Bi Yujiang. The Factors that Affect Trade in Service: A Dynamic Panel Empirical Study based on Multinational Data [J]. International Economic and Trade Research, 2016(2):4-19. 